\title{
The successful founder: genetics of introduced Carduelis chloris (greenfinch) populations in New Zealand
}

\author{
JUHA MERILÄ†+* MATS BJÖRKLUND $\uparrow \&$ ALLAN J. BAKER $\$$ \\ $\nmid$ Department of Zoology, Uppsala University, Villavägen 9, S-752 36, Uppsala, Sweden and $\ddagger$ Department of \\ Ornithology and Laboratory of Molecular Systematics, Royal Ontario Museum, 100 Queen's Park, Toronto, Ontario, \\ Canada M5S 2 C6
}

\begin{abstract}
The amount and distribution of genetic variation in seven introduced New Zealand populations of Carduelis chloris were assessed at 40 loci using starch gel electrophoresis and compared with those in native European populations. Fewer alleles (1.45) and fewer polymorphic loci (33 per cent) were detected across the introduced populations than across native populations $(1.75,55$ per cent), reflecting the narrow geographical origin of the introduced populations. There was no evidence for severe inbreeding or genetic drift as the levels of average heterozygosity $(H=0.025)$, percentage polymorphic loci $(P=16.9)$ and average number of alleles per locus $(A=1.22)$ were indistinguishable from levels observed within European populations $(H=0.025, P=14.1, A=1.19)$. Furthermore, introduced populations were genetically less weakly differentiated $\left(F_{\mathrm{ST}}=0.022\right)$ than native populations $\left(F_{\mathrm{ST}}=0.041\right)$, indicating that little genetic drift has been involved in the colonization of the new range. Similar levels of genetic variability in native and introduced greenfinch populations are consistent with theoretical expectations as the founder population size was relatively large $(>60$ individuals) and a rapid increase in population size directly after colonization was documented. A review of earlier studies on introduced birds also revealed that reductions in levels of genetic variability seem to be inversely proportional to the size of the founder population, and that less variation has been lost if the rate of population growth directly after introduction was fast.
\end{abstract}

Keywords: bottleneck, Carduelis chloris, heterozygosity, introduced species.

\section{Introduction}

Colonization events, including human-assisted introductions, often entail severe reduction in population size and permanent isolation from a larger parental population. The genetic consequences of the founding event may include rapid alteration and loss of genetic variation (Nei et al., 1975; Templeton, 1980; Watterson, 1984) and sometimes changes of sufficient magnitude to influence the evolutionary fate of the species (Barton \& Charlesworth, 1984; Carson \& Templeton, 1984). Both theoretical (e.g. Nei et al., 1975) and experimental (Verspoor, 1988; Polans \& Allard, 1989; McCommas \& Bryant, 1990; Leberg,

*Corresponding author and present address: Juha Merila, Laboratory of Ecology and Animal Systematics, Department of Biology, University of Turku, FIN-20014 Turku, Finland. Fax: +358-21-333 65 50. E-mail: juha.merila@zoologi.uu.se.
1992) results emphasize the importance of the propagule size and the rate of population growth. The reduction in genetic variability arising from sampling errors (some allelic forms not included in the propagule, some lost by chance) and inbreeding is inversely proportional to the initial size of the founder population and the length of time it remains small (Nei et al., 1975).

Although population bottlenecks have been rather frequently invoked to explain low genetic variability in natural populations, there are few studies where both the actual magnitude of the bottleneck and its genetic consequences have been established (but see: Bonnell \& Selander, 1974; Hoelzel et al., 1995). General exceptions, however, are the many humanassisted introductions where the number of founding individuals is often known quite accurately (e.g. Thomson, 1922; Long, 1981). Several studies of 
introduced plant (e.g. Schwaegerle \& Schaal, 1979; Clegg \& Brown, 1983; Glover \& Barret, 1987) and animal (e.g. Taylor \& Gorman, 1975; Baker \& Mooed, 1987) populations have found reduced levels of genetic variability in introduced as compared to native populations, although equally many have failed to confirm this (e.g. plants: Burdon \& Brown, 1986; Warwick et al., 1987; MolinaFreaner \& Jain, 1992; Novak \& Mack, 1993; animals: Ross, 1983; Baker, 1992). There are several possible explanations for these discrepancies which can be classified into two categories: technical and biological. Technical problems which could account for the failure to detect a change in genetic parameters, even though it has in fact happened, include generally invariable allozyme markers, small and variable sample sizes and, hence, inconclusive statistical tests. Biological explanations for lack of reduction in genetic variability following a bottleneck include maintainance of large effective population size during the bottleneck and fast population growth directly after the passage through the bottleneck.

The aim of this study was two-fold. First, to estimate levels of genetic variation within and among seven introduced populations of greenfinches in New Zealand, and to compare them with corresponding values from the native populations in Europe. Secondly, to review the earlier surveys of genetic variability of introduced bird species and relate the changes in genetic parameters with the known circumstances around their introduction.

\section{Methods}

\section{The study species and introduction history}

The greenfinch (Carduelis chloris) is a medium-sized seed-eating passerine bird native to the western Palaearctic region. It is a gregarious, partially migratory species which inhabits forest edges, grasslands with scattered bushes and cultivated areas such as parks and gardens (Cramp \& Perrins, 1994). Breeding takes place in loose colonies, and two to three clutches are laid annually (Cramp \& Perrins, 1994). As for many other birds, the greenfinch was successfully introduced to New Zealand and Australia during the 19th century. What is known about the introduction history in New Zealand is that several releases took place between 1862 and 1868. In 1862, the Nelson Acclimatisation Society introduced five birds, but there are no further records of them (Long, 1981). A pair of birds which produced at least two successful clutches in the wild was released in 1863 at Christchurch (Lever, 1987). The Auckland Society released several birds in 1865,18 in 1867 , and 33 in 1868 (Long, 1981; Lever, 1987) and the Otago Society released eight birds in 1868 (Long, 1981). Hence, at least 64 individuals were recorded as being released, but the true number might have been higher. By 1870 greenfinches were considered to be 'so well established that no further releases were necessary' (Lever, 1987) and by 1920 they were reported to be abundant in all the settled parts of the country (Thompson, 1922), and later dispersal to several offshore islands testifies to the success of colonization (e.g. Lever, 1987).

\section{General methods}

The material for this study was collected in Novembers 1992 and 1993 from seven localities in the two main islands of New Zealand (Fig. 1). Sample sizes with associated collecting dates are given in Table 1. Pectoral muscle, heart, liver and kidneys were removed from birds in the field, frozen in liquid nitrogen, and maintained at $-80^{\circ} \mathrm{C}$ in the laboratory. Homogenates of tissue mixture were surveyed electrophoretically for the products of 40 enzyme loci using horizontal starch gel electrophoresis. The loci and methods were the same as used in an earlier survey of the genetic variability of native greenfinch populations (Merilä et al., 1996). In short, the 40 scored loci and their Enzyme Commission number (International Union of Biochemistry and Molecular Biology, 1992) were: ACON 1 and 2 (4.2.1.3), $A C P$ (3.1.3.2), $A K 1$ and 2 (2.7.4.3), $\alpha-G P D H 1$ and 2 (1.1.1.8), $C K 1,2$ and 3 (2.7.3.2), EAP 1 and 2 (3.4.23.24), ES 1, 2 and 3 (3.1.1.1), FL-ES (3.1.1.1), G6PDH (1.1.1.49), GLUD (1.4.1.2), GOT 1 and 2 (2.6.1.1), GP 1, 2 and 3 (non-specific protein, 'general protein'), GPI (5.3.1.9), ICD 1 and 2 (1.1.1.42), $L D H 1$ and 2 (1.1.1.27), MDH 1 and 2 (1.1.1.37), MPI (5.3.1.8), NP (2.4.2.1), PEP ' $A$ ' and ' $B$ ' (3.4.11), $6 P G D$ (1.1.1.43), $P G M 1$ and 2 (5.4.2.2), SOD 1 and 2 (1.15.1.1) and SDH (1.1.1.14). Details of electrophoretic conditions can be found in Merilä et al. (1996).

\section{Statistical analyses}

Allele frequencies were calculated from genotype frequencies observed in zymograms using the BIOSYS-1 computer program (Swofford \& Selander, 1989). Genotype frequencies were tested for Hardy-Weinberg equilibrium with exact tests using the GENEPOP package (Raymond \& Rousset, 1995a,b). Adjustment for multiple tests was made by using the 
sequential Bonferroni correction (Rice, 1989) as suggested by Lessios (1992). All loci were also tested for linkage disequilibrium using exact tests (Raymond \& Rousset, 1995a); significant deviations from linkage equilibrium were detected in four of the 69 possible tests $(P<0.05)$. However, these cases involved different pairs of loci and were not significant after sequential Bonferroni correction. For

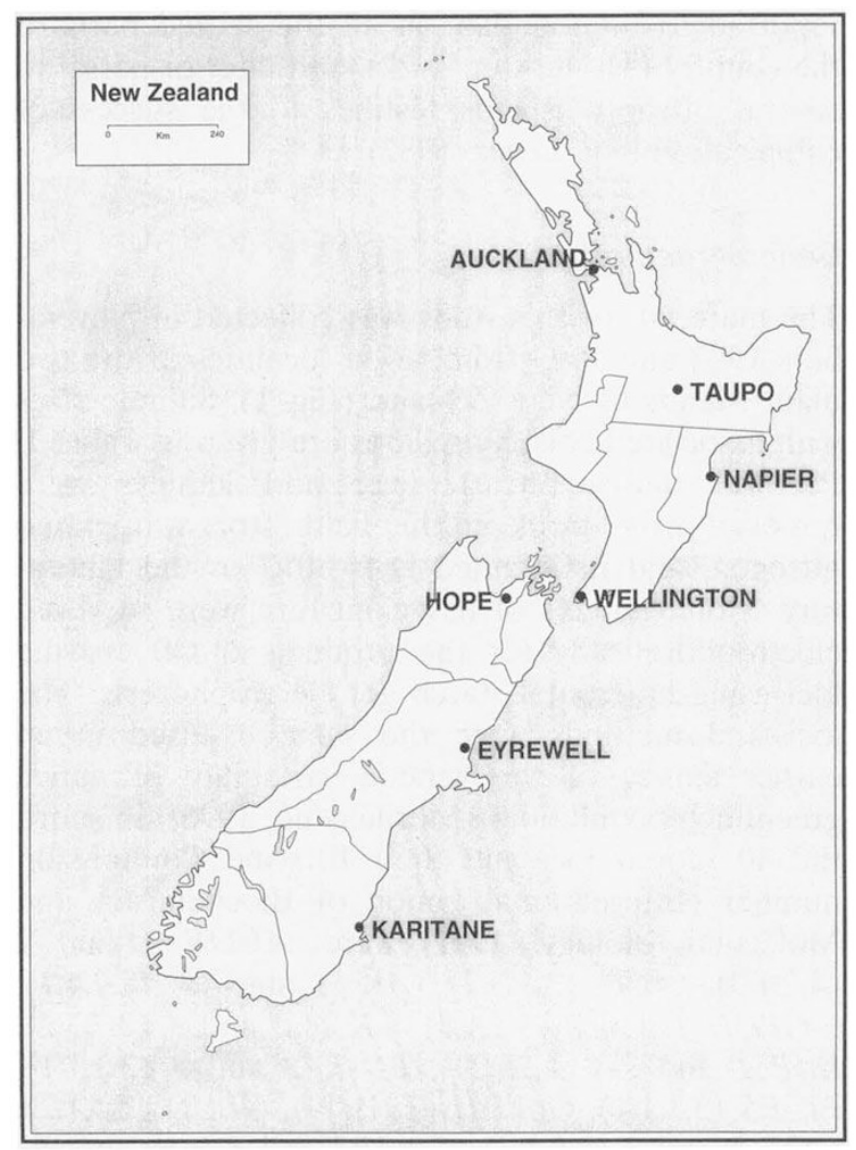

Fig. 1 Map of the collecting localities of introduced populations of greenfinch, Carduelis chloris, populations in New Zealand. each population, we computed the average observed (direct count) and average expected heterozygosity (unbiased estimate of Nei, 1978) using Blosys-1. Differences among populations in average heterozygosity and mean number of alleles per locus were assessed using the Kruskal-Wallis analysis of variance (Sokal \& Rohlf, 1981; Archie, 1985).

Recent population bottlenecks are predicted to produce an excess of alleles segregating in low frequencies (Chakraborty et al., 1980; see also Barrowclough et al., 1985). Therefore, we compared observed and expected numbers of rare $(q \leq 0.05)$ and common alleles $(p>0.95)$ in each of the study populations. The expected number of alleles in these frequency classes was calculated using the infiniteallele model with varying mutation rate (Model IV; Chakraborty et al., 1980). The discrepancy $\left(R^{2}\right)$ between expected $(E)$ and observed $(O)$ number of alleles in a given frequency class was calculated as: $R^{2}=(O-E)^{2} / E$, and its significance was tested using a randomization procedure with 9999 permutations.

$F$-statistics were used to investigate the extent of population structuring and genetic differentiation. $F_{\mathrm{ST}}$, defined as a standardized genetic variance among (sub)populations, was estimated using two different algorithms. First, to allow comparison with other studies, we calculated $G_{\mathrm{ST}}$ using the BlOSYS-1 (Swofford \& Selander, 1989) program to obtain Nei's (1986) estimate of $F_{\text {ST }}$. However, several lines of evidence indicate that Weir and Cockerham's (1984) theta $(\theta)$ estimator is a more accurate descriptor of $F_{\mathrm{ST}}$ as it includes correction terms for sample size and the number of populations examined (Weir \& Cockerham, 1984; Porter, 1990; Wolf \& Soltis, 1992; Cockerham \& Weir, 1993). Hence, we also calculated $\theta$ estimates using the FSTAT program where significance testing of $\theta$ was carried out by jackknifing over loci (Goudet, 1995). Pairwise $G_{\mathrm{ST}}$ and $\theta$ estimates were calculated using Slatkin's (1993) isolation-by-distance program.

Table 1 Greenfinch collecting localities, their coordinates, collecting dates and sample sizes $(n)$

\begin{tabular}{lllllr}
\hline Locality & Acronym & Island & Coordinates & Collecting date & $n$ \\
\hline Auckland & AUC & North & $36^{\circ} 40^{\prime} 174^{\circ} 28^{\prime}$ & November 1993 & 42 \\
Taupo & TAU & North & $38^{\circ} 42^{\prime} 176^{\circ} 06^{\prime}$ & November 1993 & 15 \\
Napier & NAP & North & $39^{\circ} 29^{\prime} 176^{\circ} 58^{\prime}$ & November 1993 & 42 \\
Wellington & WEL & North & $40^{\circ} 11^{\prime} 175^{\circ} 23^{\prime}$ & November 1992 & 29 \\
Hope & HOP & South & $41^{\circ} 21^{\prime} 173^{\circ} 09^{\prime}$ & November 1993 & 40 \\
Eyrewell & EYE & South & $43^{\circ} 18^{\prime} 172^{\circ} 11^{\prime}$ & November 1993 & 39 \\
Karitane & KAR & South & $45^{\circ} 52^{\prime} 170^{\circ} 30^{\prime}$ & November 1993 & 39 \\
& & & & $\sum$ & 246 \\
\hline
\end{tabular}


Multilocus genetical comparisons among samples were made using Rogers's (1972) genetic distances. Unlike $F_{\mathrm{ST}}$, genetic distances are not affected by levels of polymorphism within populations, and therefore they provide a way of assessing differentiation on an absolute scale. Rogers's distances were subjected to cluster analysis by using the NeighbourJoining method of Saitou \& Nei (1987) as implemented in PHYLIP (Felsenstein, 1993). Fifteen different random orderings of populations were tried to ensure that the resulting trees were not sensitive to the input order of populations.

To examine the relationship between geographical distance and different measures of genetic differentiation, a matrix of geographical distances between sites was calculated using the geographical coordinates for each site (Table 1). To avoid the distortion affecting ordinary map projections, this was carried out by measuring the shortest distance between two points as given by the great circle track connecting them (e.g. Korsström, 1927). Statistical testing of all matrix correlations $\left(r_{\mathrm{M}}\right)$ was carried out using normalized Mantel statistics $(Z)$ with a randomization approach (e.g. Manly, 1991). Five thousand random permutations were used and $P$ taken as the proportion of permutations with $Z$-values higher than the observed.

\section{Comparative analyses}

The data used in the comparative analyses include six earlier bird studies where information on genetic variability was available both from native and introduced ranges. Where variability estimates were not given in the respective publications, they were estimated from allele frequency data using BIosys-1. Information on history of introduction was obtained from the publications and from Thomson (1922), Long (1981) and Lever (1987). The total numbers of individuals recorded in these references were taken as the sizes of the founder populations. For most species, this is a minimum estimate and a rough approximation as the records are seldom complete and an unknown additional number of birds was probably released (e.g. Thomson, 1922). The number of years between first liberation and the time when the species was recorded to be abundant was taken as an indicator of the population growth rate immediately after introduction. When information for several widely separated introductions of the same species was available, they were all included separately acknowledging that they represent nonindependent observations. As the different populations of the same species are not statistically independent, and the number of species for which data were available was small, no statistical tests were carried out.

\section{Results}

\section{Variation across the native and introduced populations}

Twenty-seven of the studied loci $(A C P, A K 1-2$, CK1-3, 6PGD, GLUD, GOT1-2, $\alpha-G P D H 1-2$, GP1-3, EAP1-2, ES1 and 3,ICD1, MDH2, NP, $P G M 1, S O D 1-2, S D H$ and $F L-E S)$ were monomorphic in all introduced populations, whereas the remaining 13 loci were polymorphic in at least one of the samples (Table 2). Of these same loci, 22 were found to be polymorphic within the native range (Merilä et al. submitted; Table 3). Hence, the percentage of polymorphic loci in the introduced range $(P=33.0$ per cent) was significantly lower than in the native range $(P=55.0$ per cent; $\chi_{1}^{2}=4.11, P=0.042$ ), as was the mean number of alleles per locus (Table 3; Fig. 2). The alleles which occurred in the native range but not in the introduced range tended to segregate in lower frequencies (Table 4) and occurred in significantly fewer populations than alternative alleles which were present in both ranges (Table 4). A logistic regression analysis revealed that the average frequency of the alternative allele in native populations was a poor predictor of its presence or absence in introduced populations (Table 5). However, the presence or absence of a particular allele was well predicted by the number of native populations in which it occurred (Table 5).

Three alleles present in New Zealand samples were not found in our survey of European populations. These alleles (at loci: $A C O N 1-2$ and $G P I$ ) were found in one or two populations only and segregated at low frequencies $(q<0.05$; Table 2$)$.

\section{Variation within introduced populations}

Levels of genetic variation within all seven introduced populations were low (Table 6), and there were no significant differences in mean percentage (99 per cent criterion) polymorphic loci $\left(\chi_{6}^{2}=4.91\right.$, $P=0.56$ ), mean number of alleles per locus (Kruskall-Wallis; $H_{6}=4.70, P=0.58$ ) or average heterozygosity (Kruskall-Wallis; $H_{6}=4.43, \quad P=0.62$ ) between the different introduced populations (Table 6). Likewise, levels of within-population genetic variability did not differ between native and introduced populations as revealed by comparison of mean 
Table 2 Allele frequencies at 13 polymorphic loci in introduced greenfinch populations in New Zealand

\begin{tabular}{|c|c|c|c|c|c|c|c|c|}
\hline \multirow[b]{2}{*}{ Locus } & \multirow[b]{2}{*}{ Allele } & \multicolumn{7}{|c|}{ Population and sample size } \\
\hline & & $\begin{array}{c}\text { WEL } \\
29\end{array}$ & $\begin{array}{c}\text { AUC } \\
42\end{array}$ & $\begin{array}{c}\text { TAU } \\
15\end{array}$ & $\begin{array}{c}\text { NAP } \\
42\end{array}$ & $\begin{array}{c}\mathrm{HOP} \\
40\end{array}$ & $\begin{array}{c}\text { EYE } \\
39\end{array}$ & $\begin{array}{c}\text { KAR } \\
39\end{array}$ \\
\hline$A C O N 1$ & $\begin{array}{l}A \\
B\end{array}$ & 1.000 & 1.000 & 1.000 & 1.000 & $\begin{array}{l}0.962 \\
0.038\end{array}$ & 1.000 & 1.000 \\
\hline ACON2 & $\begin{array}{l}A \\
C\end{array}$ & $\begin{array}{l}0.983 \\
0.017\end{array}$ & 1.000 & 1.000 & 1.000 & 1.000 & 1.000 & 1.000 \\
\hline ES2 & $\begin{array}{l}A \\
B\end{array}$ & 0.810 & 0.929 & 0.833 & 0.857 & $\begin{array}{r}0.700 \\
0.063\end{array}$ & 0.859 & 0.795 \\
\hline & $C$ & 0.103 & 0.048 & 0.167 & 0.107 & 0.237 & 0.115 & 0.154 \\
\hline G6PDH & $\begin{array}{l}A \\
B\end{array}$ & $\begin{array}{l}0.845 \\
0.138\end{array}$ & $\begin{array}{l}0.929 \\
0.048\end{array}$ & 1.000 & $\begin{array}{l}0.940 \\
0.048\end{array}$ & $\begin{array}{l}0.863 \\
0.125\end{array}$ & $\begin{array}{l}0.731 \\
0.205\end{array}$ & $\begin{array}{l}0.756 \\
0.231\end{array}$ \\
\hline & C & 0.017 & 0.024 & & 0.012 & 0.013 & 0.064 & 0.013 \\
\hline$I C D 2$ & $\begin{array}{l}A \\
B\end{array}$ & $\begin{array}{l}0.983 \\
0.017\end{array}$ & $\begin{array}{l}0.988 \\
0.012\end{array}$ & 1.000 & 1.000 & 1.000 & $\begin{array}{l}0.987 \\
0.013\end{array}$ & $\begin{array}{l}0.962 \\
0.038\end{array}$ \\
\hline$L D H 1$ & $\begin{array}{l}A \\
B\end{array}$ & $\begin{array}{l}0.983 \\
0.017\end{array}$ & 1.000 & 1.000 & 1.000 & 1.000 & 1.000 & 1.000 \\
\hline$L D H 2$ & $\begin{array}{l}A \\
B\end{array}$ & $\begin{array}{l}0.983 \\
0.017\end{array}$ & 1.000 & 1.000 & 1.000 & 1.000 & 1.000 & 1.000 \\
\hline$M D H 1$ & $\begin{array}{l}A \\
B\end{array}$ & 1.000 & 1.000 & 1.000 & 1.000 & 1.000 & 1.000 & $\begin{array}{l}0.987 \\
0.013\end{array}$ \\
\hline$M P I$ & $\begin{array}{l}A \\
B\end{array}$ & 1.000 & 1.000 & 1.000 & $\begin{array}{l}0.988 \\
0.012\end{array}$ & 1.000 & 1.000 & 1.000 \\
\hline$P E P A$ & $\begin{array}{l}A \\
B \\
C\end{array}$ & $\begin{array}{l}0.983 \\
0.017\end{array}$ & 1.000 & 1.000 & $\begin{array}{l}0.964 \\
0.036\end{array}$ & $\begin{array}{l}0.988 \\
0.013\end{array}$ & 1.000 & 0.974 \\
\hline$P E P B$ & $\begin{array}{l}A \\
C \\
D\end{array}$ & $\begin{array}{l}0.810 \\
0.190\end{array}$ & $\begin{array}{l}0.810 \\
0.190\end{array}$ & $\begin{array}{l}0.867 \\
0.133\end{array}$ & $\begin{array}{l}0.833 \\
0.071 \\
0.095\end{array}$ & $\begin{array}{l}0.913 \\
0.087\end{array}$ & $\begin{array}{l}0.795 \\
0.192 \\
0.013\end{array}$ & $\begin{array}{l}0.744 \\
0.256\end{array}$ \\
\hline$G P I$ & $\begin{array}{l}A \\
C \\
D\end{array}$ & $\begin{array}{l}0.966 \\
0.017 \\
0.017\end{array}$ & $\begin{array}{l}0.976 \\
0.024\end{array}$ & 0.967 & $\begin{array}{l}0.988 \\
0.012\end{array}$ & $\begin{array}{l}0.988 \\
0.013\end{array}$ & $\begin{array}{l}0.974 \\
0.026\end{array}$ & $\begin{array}{l}0.987 \\
0.013\end{array}$ \\
\hline$P G M 2$ & $\begin{array}{l}A \\
B\end{array}$ & $\begin{array}{l}0.948 \\
0.052\end{array}$ & $\begin{array}{l}0.917 \\
0.083\end{array}$ & 1.000 & $\begin{array}{l}0.952 \\
0.048\end{array}$ & $\begin{array}{l}0.988 \\
0.013\end{array}$ & $\begin{array}{l}0.936 \\
0.064\end{array}$ & $\begin{array}{l}0.987 \\
0.013\end{array}$ \\
\hline
\end{tabular}

Table 3 Number of populations ( $\left.n_{\mathrm{POP}}\right)$, number of alleles $\left(A_{\text {TOT }}\right)$, mean number of alleles per locus $(A)$, and number of polymorphic loci $\left(P_{\text {TOT }}\right)$ in introduced and native populations of greenfinch. Note that this comparsion was made pooling all individuals in the respective ranges and using each locus $(n=40)$ as a unit of comparison

\begin{tabular}{lccccc}
\hline Range & $n_{\text {POP }}$ & $A_{\text {TOT }}$ & $A$ & $P_{\text {TOT }}$ & Polymorphic loci (\%) \\
\hline Introduced & 7 & 58 & $1.45 \pm 0.11$ & 13 & $33 \%$ \\
Native $\dagger$ & 14 & 70 & $1.75 \pm 0.14$ & 22 & $55 \%$ \\
& & & $z \ddagger=3.0^{* *}$ & & $\chi^{2}{ }_{1}=4.11^{*}$ \\
\hline
\end{tabular}

$\dagger$ Data from Merilä et al. (1996), †Mann-Whitney.

${ }^{*} P<0.05,{ }^{* *} P<0.01$ 


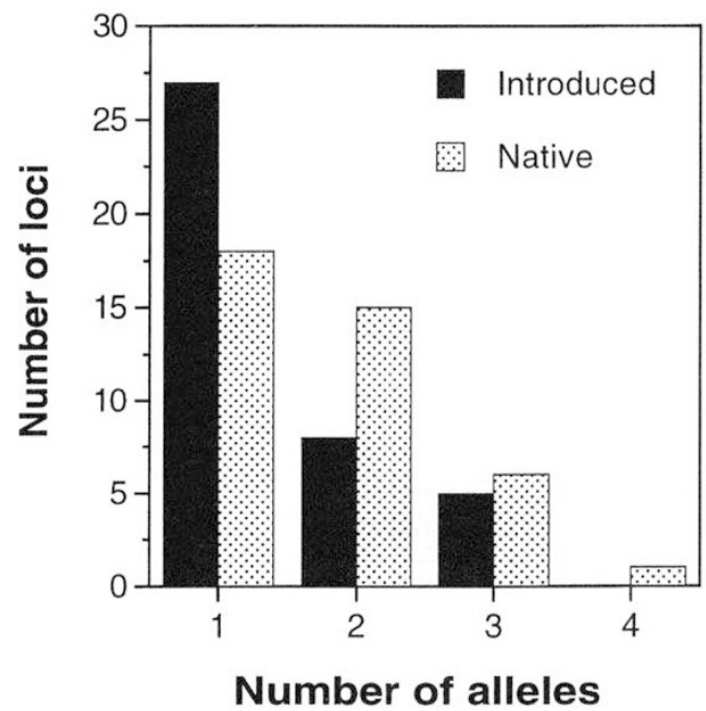

Fig. 2 The distribution of 40 loci with different numbers of alleles in native and introduced ranges of the greenfinch, Carduelis chloris. The proportion of monomorphic loci is significantly higher in introduced than in native populations $\left(\chi_{1}^{2}=4.11, P<0.05\right)$. Data for European populations from Merilä et al. (1996).

Table 4 Average frequency and average number of greenfinch populations containing alternative (all but the most common allele) alleles in the native range that were present or absent in the introduced range

\begin{tabular}{lccc}
\hline & $\begin{array}{c}\text { Allele } \\
\text { frequency } \\
(\text { mean } \pm \text { SE) }\end{array}$ & $\begin{array}{c}\text { No. of populations } \\
\text { occupied } \\
\text { (mean } \pm \text { SE) }\end{array}$ & $n$ \\
\hline Present & $0.051 \pm 0.013$ & $5.5 \pm 1.21$ & 16 \\
Absent & $0.022 \pm 0.006$ & $1.5 \pm 0.17$ & 14 \\
$z \dagger$ & 1.69 & 2.29 & \\
$P$ & 0.09 & 0.02 & \\
\hline
\end{tabular}

$†$ Mann-Whitney. percentage polymorphic loci, mean number of alleles per locus or average heterozygosity (Table 7).

\section{Conformation to Hardy-Weinberg expectations}

A straightforward prediction, under the assumption that introduced greenfinches have suffered from severe inbreeding and genetic drift, is that there should initially be greater departures from randommating genotype frequencies in introduced than in native populations (e.g. Berlocher, 1984). However, significant $(P<0.05)$ departures from Hardy-Weinberg equilibrium were detected in only five of the 31 possible tests, and all were heterozygote deficiencies (not significant after sequential Bonferroni correction: $P>0.05)$. Furthermore, comparison of $F_{1 \mathrm{~S}}$ values among introduced (0.124) and native (0.133) populations gave no indication of a greater degree of inbreeding in the introduced populations.

The number of alleles segregating at low frequencies $(q \leq 0.05)$ was very similar to the value to be expected according to a null-model (Table 8). Only in one population (Taupo) did the observed frequency differ from the expected one, but after sequential Bonferroni correction, this difference was not significant (Table 8).

\section{Differentiation among introduced populations}

The degree of differentiation among introduced populations was weak as allele frequencies in only four out of 13 polymorphic loci were significantly heterogeneous (G6PDH, PEPB, ES2, ACON1; exact tests; $P<0.05)$. Accordingly, $F_{\mathrm{ST}}$ as estimated by theta $(\theta)$ was small $(\theta=0.022)$ and almost two times lower than among native populations $(\theta=0.041)$. The $F_{\mathrm{ST}}$ estimate based on $G_{\mathrm{ST}}$ was somewhat higher $\left(G_{\mathrm{ST}}=0.033\right)$ but, again, considerably lower than the estimate for native populations $\left(G_{\mathrm{ST}}=0.090\right)$.

Table 5 Logistic regression of presence/absence of alternative alleles in the introduced range as a function of their average frequency (Model I) and distribution ( = number of populations containing them; Model II) in the native range. Model III considers both factors simultaneously. $R$, Standardized regression coefficient. $L R, \log$ likehood ratio. Per cent correct, percentage of correctly classified cases

\begin{tabular}{llrrrc}
\hline & Variable & \multicolumn{1}{c}{$R$} & $-2 \log L R$ & $P$ & Per cent correct \\
\hline Model I & Frequency & -0.07 & 3.78 & 0.052 & $66.7 \%$ \\
Model II & Distribution & -0.21 & 10.95 & $<0.001$ & $80.0 \%$ \\
Model III & Frequency & 0.00 & 0.56 & 0.45 & $73.3 \%$ \\
& Distribution & -0.21 & 7.74 & 0.005 & \\
\hline
\end{tabular}


Table 6 Genetic variability measures for 40 loci in seven introduced greenfinch populations in New Zealand

\begin{tabular}{|c|c|c|c|c|c|c|}
\hline \multirow[b]{2}{*}{ Population } & \multirow[b]{2}{*}{$n$} & \multirow[b]{2}{*}{$A \pm \mathrm{SE}$} & \multicolumn{2}{|c|}{ Polymorphic loci $(P)$} & \multicolumn{2}{|c|}{ Heterozygosity $( \pm S E)$} \\
\hline & & & $\leq 95 \%$ & $\leq 99 \%$ & Observed $\left(H_{\mathrm{O}}\right)$ & $\mathrm{H}-\mathrm{W}$ expected $\dagger\left(H_{\mathrm{E}}\right)$ \\
\hline Auckland & 42.0 & $1.20 \pm 0.08$ & 10.0 & 15.0 & $0.020 \pm 0.011$ & $0.020 \pm 0.010$ \\
\hline Taupo & 15.0 & $1.08 \pm 0.04$ & 5.0 & 7.5 & $0.010 \pm 0.006$ & $0.015 \pm 0.009$ \\
\hline Napier & 42.0 & $1.25 \pm 0.09$ & 7.5 & 17.5 & $0.020 \pm 0.009$ & $0.022 \pm 0.010$ \\
\hline Wellington & 29.0 & $1.33 \pm 0.10$ & 10.0 & 25.0 & $0.023 \pm 0.009$ & $0.031 \pm 0.013$ \\
\hline Hope & 40.0 & $1.23 \pm 0.08$ & 7.5 & 17.5 & $0.022 \pm 0.012$ & $0.025 \pm 0.013$ \\
\hline Eyrewell & 39.0 & $1.23 \pm 0.09$ & 10.0 & 15.0 & $0.027 \pm 0.014$ & $0.030 \pm 0.015$ \\
\hline Karitane & 39.0 & $1.25 \pm 0.09$ & 7.5 & 20.0 & $0.029 \pm 0.014$ & $0.033 \pm 0.016$ \\
\hline Mean & 35.1 & $1.22 \pm 0.03$ & $8.2 \pm 0.71$ & $16.8 \pm 2.02$ & $0.023 \pm 0.003$ & $0.025 \pm 0.002$ \\
\hline
\end{tabular}

$A$, mean number of alleles per locus; $n$, mean sample size per locus.

$\dagger$ Nei's unbiased estimate (Nei, 1978).

Fig. 3 Genetic similarity among introduced (New Zealand) and native (Europe and North Africa) populations of greenfinches as revealed by Neighbour-Joining analysis of Rogers's (1972) genetic distances. Data for European populations from Merilä et al. (1996).
Table 7 Comparison of genetic variability in native European and introduced New Zealand populations of greenfinch

\begin{tabular}{lrccc}
\hline Population & $n$ & $\begin{array}{c}\text { \% Polymorphic } \\
\text { loci }\end{array}$ & $\begin{array}{c}\text { Mean number } \\
\text { of alleles/locus }\end{array}$ & $\begin{array}{c}\text { Average expected } \\
\text { heterozygosity }\end{array}$ \\
\hline Native & 14 & $14.1 \pm 0.87 \%$ & $1.19 \pm 0.02$ & $0.025 \pm 0.002$ \\
Introduced & 7 & $16.8 \pm 2.02 \%$ & $1.22 \pm 0.03$ & $0.025 \pm 0.002$ \\
$z \dagger$ & & 1.58 & 1.13 & 0.64 \\
$P$ & 0.11 & 0.26 & 0.52 \\
\hline
\end{tabular}

$n$, number of populations.

$\uparrow$ Mann-Whitney.
Comparison of $F_{\mathrm{ST}}$ estimates and Rogers's genetic distances between North $\left(G_{\mathrm{ST}}=0.02 ; D_{\mathrm{R}}=0.01\right)$ and South $\left(F_{\mathrm{ST}}=0.022, \quad D_{\mathrm{R}}=0.01\right)$ islands revealed similar levels of differentiation within both islands.
Despite the low degree of differentiation, there was a weak geographical component to differentiation as both $F_{\mathrm{ST}}\left(r_{\mathrm{M}}=0.69, n=21, P=0.003\right)$ and Rogers's genetic distances $\left(r_{\mathrm{M}}=0.47, n=21, P=0.028\right)$ were 
positively correlated with geographical distance separating pairs of introduced populations. Furthermore, cluster analysis of Rogers's genetic distances using the Neighbour-Joining algorithm indicated some correspondence between geography and genetic similarity as all New Zealand populations clustered together (Fig. 3). This figure further shows that the branch lengths in New Zealand are equivalent to those in northern Europe, indicating roughly similar levels of differentiation within introduced and native ranges (Fig. 3).

\section{Comparative analyses}

The seven species for which genetic variability has been assayed both in introduced and native populations, together with summary statistics, are listed in Table 9. Clearly, introduced populations do not

Table 8 Expected and observed numbers of rare alleles in different introduced greenfinch populations

\begin{tabular}{lcccc}
\hline & \multicolumn{2}{l}{ Number of rare alleles } & & \\
\cline { 2 - 3 } Population & Expected & Observed & & $R^{2}$ \\
& & & $P$ \\
\hline Wellington & 7.1 & 8 & 0.110 & 0.97 \\
Auckland & 4.8 & 6 & 0.298 & 0.78 \\
Taupo & 2.9 & 1 & 1.274 & 0.02 \\
Napier & 5.3 & 7 & 0.543 & 0.77 \\
Hope & 6.0 & 5 & 0.170 & 0.80 \\
Eyrewell & 7.3 & 4 & 1.457 & 0.27 \\
Karitane & 8.0 & 5 & 1.138 & 0.42 \\
\hline
\end{tabular}

consistently have lower numbers of alleles per locus, fewer polymorphic loci, or lower average heterozygosities. In fact, the opposite is true in a number of instances (Table 9).

Data about the history of introduction - number of introduced individuals, number of introductions, and number of years lapsed between release and abundance - are presented in Table 9. The relationships between the differences in levels of genetic variability and parameters that are supposed to reflect population history are illustrated for native and introduced populations in Fig. 4. The 'reduction' in levels of genetic variation, whether measured by mean number of alleles per locus, percentage polymorphic loci, or average heterozygosity, shows a negative association with 'founder population size' and with number of introductions, and a positive association with the time to become described as abundant (Fig. 4).

\section{Discussion}

\section{Variation within introduced populations}

We found no evidence for a severe reduction in genetic variability in greenfinch populations introduced into New Zealand as compared to that observed in native European populations. Some alleles found in the native range were missing from the New Zealand populations, but this may be attributable to the more restricted scope of sampling of original source populations, as compared to the range of native populations included in this study, rather than to any effects of the introduction per se. Furthermore, as a consequence of inbreeding and
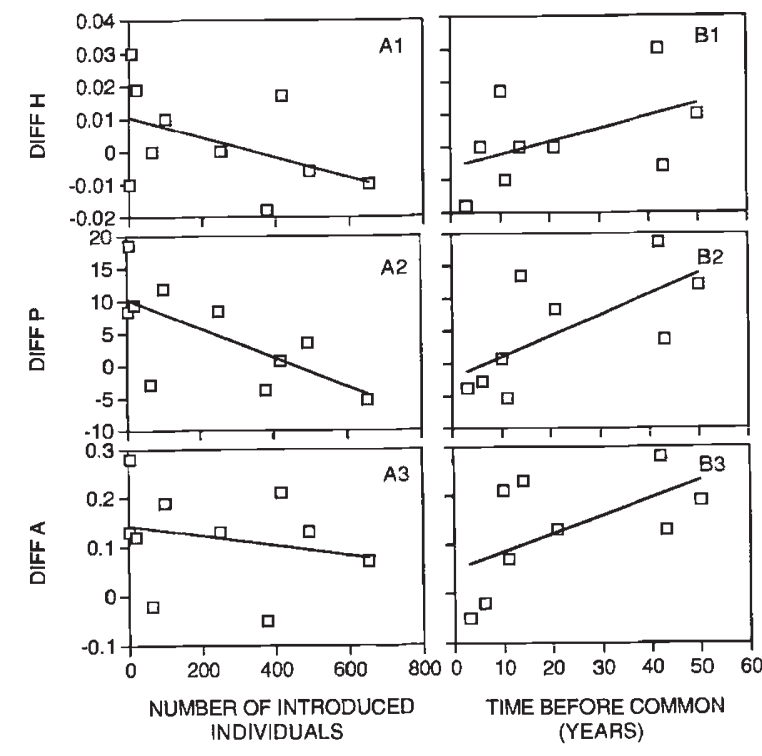

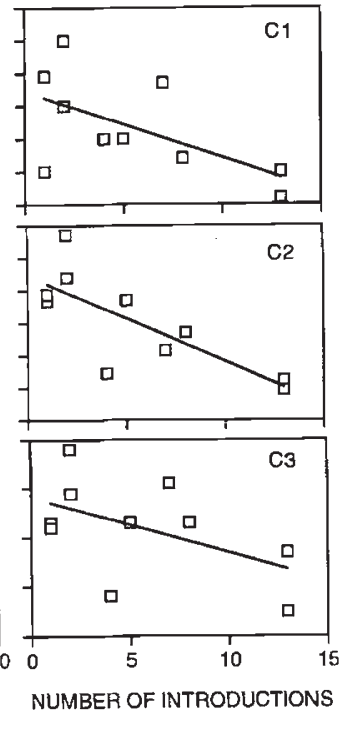

Fig. 4 Differences in levels of genetic variability between native and introduced populations of birds as a function of (A1-A3) number of introduced individuals, (B1-B3) time elapsed between introduction and expansion and (C1-C3) number of introductions. See Table 9 for details. The lines are linear regressions. 
Table 9 Comparison of genetic variability in native and introduced bird populations

\begin{tabular}{|c|c|c|c|c|c|c|c|c|c|c|}
\hline \multirow[b]{2}{*}{ Species } & \multirow[b]{2}{*}{ Area $†$} & \multirow[b]{2}{*}{$n_{\mathrm{P}}$} & \multirow[b]{2}{*}{$n_{\mathrm{I}}$} & \multicolumn{3}{|c|}{ Genetic parameters } & \multicolumn{4}{|c|}{ Introduction history } \\
\hline & & & & $A$ & $P$ & $H_{\mathrm{E}}$ & Intro. & Abun. & $n$ & \#times \\
\hline Sturnus vulgaris ${ }^{1}$ & $\mathrm{NZ}$ & 6 & 24.0 & 1.35 & 33.8 & 0.043 & 1867 & 1878 & 653 & 13 \\
\hline \multirow[t]{4}{*}{ Acridotheres tristis ${ }^{2}$} & Native & 7 & 28.4 & 1.43 & 31.5 & 0.060 & - & - & - & - \\
\hline & $\mathrm{HA}$ & 1 & 37.6 & 1.20 & 18.0 & 0.060 & 1865 & 1879 & - & - \\
\hline & FI & 2 & 25.9 & 1.30 & 20.6 & 0.050 & & - & - & - \\
\hline & $\mathrm{SA}$ & 2 & 38.3 & 1.15 & 12.9 & 0.030 & 1888 & 1930 & 6 & 2 \\
\hline \multirow[t]{2}{*}{ Fringilla coelebs ${ }^{3}$} & Native & 10 & 28.7 & 1.34 & 24.5 & 0.048 & - & - & - & - \\
\hline & NZ & 8 & 26.1 & 1.39 & 28.3 & 0.066 & 1867 & 1870 & 377 & 13 \\
\hline Carpodacus mexicanus ${ }^{4}$ & Native & 6 & 40.6 & 1.48 & 27.4 & 0.045 & - & - & - & - \\
\hline Carduelis chloris $^{5}$ & NZ & 7 & 35.1 & 1.22 & 16.8 & 0.025 & 1862 & 1868 & 64 & 5 \\
\hline \multirow[t]{3}{*}{ Passer montanus ${ }^{6}$} & Native & 2 & 55 & 1.45 & 33.3 & 0.098 & - & - & - & - \\
\hline & USA & 3 & 83 & 1.33 & 23.9 & 0.078 & 1870 & - & 20 & 1 \\
\hline & AU & 1 & 15 & 1.3 & 23.1 & 0.074 & 1863 & - & - & - \\
\hline \multirow[t]{3}{*}{ Passer domesticus ${ }^{7} \ddagger$} & Native & 14 & 60.7 & 1.63 & 36.9 & 0.097 & - & - & - & - \\
\hline & NZ & 4 & 51.4 & 1.42 & 36.2 & 0.080 & 1859 & 1869 & 418 & 7 \\
\hline & $\mathrm{AU}$ & 3 & 36.7 & 1.50 & 33.3 & 0.103 & 1863 & 1906 & 494 & 8 \\
\hline
\end{tabular}

${ }^{1}$ Ross, 1983; ${ }^{2}$ Baker \& Moeed, 1987; ${ }^{3}$ Baker, 1992, Baker et al., 1990; ${ }^{4}$ Vásquez Phillips, 1992, ${ }^{5}$ This study; ${ }^{6}$ St. Louis \& Barlow, 1988; ${ }^{7}$ Parkin \& Cole, 1985.

$n_{\mathrm{P}}$, number of populations; $n_{\mathrm{I}}$, average number of individuals scored per locus; $A$, average number of alleles per locus; $P$, percentage polymorphic loci; $H_{\mathrm{E}}$, average expected heterozygosity; $n$, minimum number of introduced individuals; \#times, minimum number of introductions.

$\dagger$ AU, Australia; E-USA, Eastern USA; FI, Fiji; HA, Hawaii; NZ, New Zealand; SA, South Africa.

$\ddagger$ Only loci scored in all populations included.

drift, severe bottlenecks should also reduce average heterozygosity and elevate the inbreeding coefficient $\left(F_{\mathrm{IS}}\right)$, but none of these expectations was met in our data. This agrees with the fact that several plant (e.g. Burdon \& Brown, 1986; Warwick et al., 1987; Molina-Freaner \& Jain, 1992; Novak \& Mack, 1993) and animal (e.g. Ross, 1983; Baker, 1992) studies have found little or no reduction in the levels of within-population genetic variability in introduced populations when compared to native ones. Other studies have demonstrated reduced levels of variability in introduced populations (plants: Clegg \& Brown, 1983; Glover \& Barret, 1987; insects: Bryant et al., 1981; reptiles: Taylor \& Gorman, 1975; birds: Baker \& Moeed, 1987; St. Louis \& Barlow, 1988).

Theory predicts that loss of genetic variation as a result of bottlenecking is heavily dependent on the initial (effective) population size and the length of the time the population remains small (Nei et al., 1975; Maruyama \& Fuerst, 1985). The smaller the initial population size, and the longer it remains small, the more variation will be lost. Furthermore, the genetic diversity of founding populations will probably increase as the number of introductions from source population(s) increases (Wade \& McCauley, 1988; Whitlock \& McCauley, 1990). As it is well known that the numbers of founders, as well as the numbers of introductions, have differed between species (e.g. Long, 1981), differing amounts of reduction in genetic variability are to be expected. Furthermore, different species differ in their ecology and life history characteristics and, hence, in their potential for rapid increase in population size following the introduction. The introduction of the greenfinch to New Zealand involved several releases in multiple locations (Long, 1981), and the initial increase in population size was so rapid that after only three years from the first release the species was considered so well established that 'further introductions were unnecessary' (Lever, 1987). Thus, 
this rapid increase may have minimized the effects of inbreeding and genetic drift, and thereby prevented loss of alleles and reduction in heterozygosity (Nei et al., 1975). Furthermore, even if an initial reduction in genetic variation had taken place locally, it could have been quickly restored by gene flow from other populations (Polans \& Allard, 1989) - an outcome which might have applied to greenfinches as a result of multiple introductions in different parts of New Zealand.

\section{Methological considerations}

A general problem in measuring the effects of bottlenecks is that levels of genetic variation before the bottleneck are rarely known (but see Gallardo et al., 1995). Studies of introduced populations are powerful in the sense that prebottleneck levels of variation can be inferred with reasonable accuracy from levels estimated in source populations. Such a calibration is much more reliable than comparison to other outbred species (Taylor et al., 1995), although it is based upon the assumption that source populations have not passed through bottlenecks after the introduced stock was split off. Another important assumption is that levels of variability have been estimated with similar accuracy in both native and introduced populations. As the number of alleles detected is strongly dependent on sample size, less extensive sampling in introduced populations would tend to bias their variability estimates downwards. However, sample sizes from introduced populations (Table 9) are often even larger than those for native populations. In our own study, sample sizes were similar for introduced and native populations (Table 9), and hence, the main conclusion about the lack of reduction in genetic variation following the bottleneck would not be changed even if additional sampling had increased the number of detected alleles.

The source population for the greenfinches introduced to New Zealand was probably from Britain. Although we do not know the genetic parameters of this ancestral stock, we have no reason to suspect that they would differ greatly from those of other northern European populations (Merilä et al., 1996). This is because catching a large number of greenfinches is best undertaken outside of the breeding season when large flocks can be attracted to baits. If the greenfinches to be used for the introductions were captured in Britain during the nonbreeding season, many overwintering Scandinavian birds are quite likely to have been included in the samples. Furthermore, the genetic differences among different northern European populations are very small (Merilä et al., 1996) and, hence, allele frequencies in British populations are likely to be similar to those elsewhere in northern Europe. However, the presence of a few alleles in New Zealand samples that were not found in 14 native European populations (472 genomes) might derive from British populations which were not included in the previous survey (Merilä et al., 1996).

\section{Population divergence in New Zealand}

Several studies have found that introduced species have evolved a stronger population structure in the introduced range as compared to the native range (e.g. Berlocher, 1984; Baker \& Moeed, 1987; Baker \& Dennison, 1991). This is to be expected if the influence of genetic drift has been prominent in creating allele frequency differences among different populations, and if gene flow between different introduced populations has been restricted. We found that New Zealand populations of greenfinches are only weakly structured and in fact exhibit lower or similar levels of spatial differentation compared with native populations in Europe. However, given that the size of the native range (average distance between sampling localities $[ \pm \mathrm{SE}]=1830 \pm 180 \mathrm{~km}$ ) is much larger than the size of the New Zealand range $(495 \pm 60 \mathrm{~km})$, this indicates that in $\approx 100$ years, a population structure in New Zealand has evolved comparable to that in Europe. Actually, if we correct for differences in sampling range by calculating residuals from the regression of Rogers's genetic distances on the geographical distance separating pairs of populations (for combined New Zealand and European data), and compare these among native and introduced populations, there is a tendency for introduced populations to be more differentiated (Mann-Whitney: $z=1.80, n=112$, $P=0.07)$.

\section{Comparison with earlier studies}

A review of the literature on genetic variability in introduced bird species revealed that in many instances, there is little or no evidence for reduced levels of genetic variability in introduced populations (e.g. Ross, 1983; Parkin \& Cole, 1985; Baker, 1992; Vásquez-Phillips, 1992; Table 9). However, when analysed across the different studies, the degree of reduction in genetic variability seems to be inversely related to the size of the founding population and to the number of introductions (Fig. 4). Furthermore, the amount of variation lost seems to increase with 
the length of time during which the population size remained small (Fig. 4). Hence, these trends suggest, in accordance with theory (Nei et al., 1975), that only the most severe bottlenecks may result in loss of genetic variability. Hence, in spite of the small sample sizes, errors involved with estimation of genetic parameters and in particular, the very approximate nature of the demographic parameters (see methods), these data strongly suggest an association between demographic and genetic characteristics in founding populations.

There is an additional problem concerning not only this study, but the inference based on genetic studies of introduced populations as a whole. Studies of introduced populations are not based on any experimental design, and may therefore represent a non-random selection of introduced species and populations. For example, introduced bird species for which genetic data are available probably are not a random sample with respect to their ecology and life-history characteristics. Many species have been introduced, but only a minority have became successful colonists. For example, a total of 133 species of birds have been introduced into New Zealand, but only 38 of these have become successful colonists. Thirteen (34 per cent) of these successful ones are passerines (mostly multi-brooded) which are characterized by relatively large clutch sizes and high dispersal capacities. Hence, the fact that many studies have documented slight or no decrease in levels of genetic variability in introduced bird populations may to some degree reflect biased sampling rather than a small average effect of introductions. For example, small propagules, where reduction in genetic variance is most likely to be found, are also in greater peril of extinction due to demographic stochasticity. Hence, the general failure to detect reduced levels of genetic variability in introduced bird populations may not be solely attributable to methodological problems, but more likely, to the favourable demographic characteristics of these succesfully introduced species which have made the genetic studies possible.

\section{Conclusions}

Our study provides another example of an introduced species suffering no demonstratable reduction in genetic variability following the population bottleneck that any introduction inevitably entails. Similar results have been obtained for other introduced bird populations (Ross, 1983; Baker, 1992), all of which seem to be characterized by a relatively large size of founding population, multiple introductions and rapid population growth rate following the introduction. Thus, these are demographic properties that increase the probability of an introduction whether desirable or undesirable - becoming a success.

\section{Acknowledgements}

We thank Staffan Ulfstrand and anonymous refererees for thouhgtful reading of manuscript, and for several suggestions which have improved it. Special thanks to Mark Peck for his invaluable help both in field and lab. This study was financially supported by the Canadian National Environmental Research Council (to AJB), The Swedish Natural Science Research Council (to MB), The Royal Swedish Academy of Sciences, and Stiftelsen Zoologisk Forskning at Uppsala University (to JM).

\section{References}

ARCHIE, J. W. 1985. Statistical analysis of heterozygosity data: independent sample comparisons. Evolution, 39, $623-637$.

BAKER, A. J. 1992. Genetic and morphometric divergence in ancestral European and descendent New Zealand populations of chaffinches (Fringilla coelebs). Evolution, 46, 1784-1800.

BAKER, A. J. AND DENNison, M. D. 1991. Population differentiation in colonizing species of birds. In: Quellet, $\mathrm{H}$. (ed.) Acta XX Congressus Internationalis Ornithologici, pp. 504-513. Ornithological Congress Trust Board, New Zealand.

BAKER, A. J. AND MOEED, A. 1987. Rapid genetic differentiation and founder effect in colonizing populations of common mynas (Acridotheres tristis). Evolution, 41, $525-538$.

BAKER, A. J., PECK, M. K. AND GOLDSMITH, M. A. 1990. Genetic and morphometric differentation of introduced populations of Common Chaffinches (Fringilla coelebs) in New Zealand. Condor, 92, 76-88.

BARROWCLOUGH, G. F., JOHNSON, N. K. AND ZINK, R. M. 1985. On the nature of genic variation in birds. Curr. Ornithol., 2, 135-154.

BARTON, N. AND CHARLESWORTH, B. 1984. Genetic revolutions, founder effects and speciation. Ann. Rev. Ecol. Syst., 15, 133-164.

BERLOCHER, S. H. 1984. Genetic changes coinciding with the colonization of California by the walnut husk fly, Rhagoletis completa. Evolution, 38, 906-918.

BONNELl, M. L. AND SELANDER, R. K. 1974. Elephant seals: genetic variation and near extinction. Science, 184, 908-909.

BRYANT, E. H., VAN DIJK, H. AND VAN DELDEN, w. 1981. Genetic variability of the face fly, Musca autumnalis De Geer, in relation to a population bottleneck. Evolution, 35, 872-881. 
BURdon, J. J. AND BROWN, A. H. D. 1986. Population genetics of Echium plantagineum L. - target weed for biological control. Aust. J. Biol. Sci., 39, 369-378.

CARSON, H. L. AND TEMPLETON, A. R. 1984. Genetic revolutions in relation to speciation phenomena: the founding of new populations. Ann. Rev. Ecol. Syst., 15, 97-131.

CHAKRABORTY, R., FUERST, P. A. AND NEl, M. 1980. Statistical studies on protein polymorphism in natural populations. III. Distribution of allele frequencies and the number of alleles per locus. Genetics, 94, 1039-1063.

ClEGG, M. T. AND BROWN, A. H. D. 1983. The founding of plant populations. In: Schonewald-Cox, C. M., Chambers, S. M., MacBryde, B. and Thomas, L. (eds) Genetics and Conservation, pp. 216-228. Benjamin Cummings, Menlo Park, CA.

COCKERHAM, C. C. AND WEIR, B. S. 1993. Estimation of gene flow from $F$-statistics. Evolution, 47, 855-863.

CRAMP, S. AND PERRINS, C. M. 1994. The Birds of the Western Palearctic, vol. VIII. Oxford University Press, Oxford.

FELSENSTEIN, J. 1993. PHYLIP (Phylogeny Inference Package) version 3.5c. (Distributed by the author.) Department of Genetics, University of Washington, Seattle.

GAllaRdo, M. H., KÖHLER, N. AND ARANEDA, C. 1995. Bottleneck effects in local populations of fossorial Ctenomys (Rodentia, Ctenomyidae) affected by vulcanism. Heredity, 74, 638-646.

GLOVER, D. E. AND BARRET, s. C. H. 1987. Genetic variation in continental island populations of Eichhornia paniculata (Pontederiaceae). Heredity, 59, 7-17.

GOUDET, J. 1995. FSTAT, a program for IBM PC compatibles to calculate Weir and Cockerham's 1984 estimators of F-statistics, ver. 1.2. Distributed by J. Goudet, University of Lausanne, Switzerland.

hoElzel, A. R., hAlley, J., o'Brien, s. J., CAMPAGNA, C., ARNBOM, T., LE BOEUF, B., RALLS, K. AND DOVER, G. A. 1995. Elephant seal genetic variation and the use of simulation models to investigate historical population bottlenecks. $J$. Hered., 84, 443-449.

INTERNATIONAL UNION OF BIOCHEMISTRY AND MOLECULAR Bıology 1992. Enzyme Nomenclature, 1992. Academic Press, San Diego, CA.

KoRsström, H. 1927. Merenkulun oppikirja. Valtion kirjapaino, Helsinki.

LEBERG, P. L. 1992. Effects of population bottlenecks on genetic diversity as measured by allozyme electrophoresis. Evolution, 46, 477-494.

LESSIOS, H. A. 1992. Testing electrophoretic data for agreement with Hardy-Weinberg expectations. Mar. Biol., 112, 517-523.

LEVER, C. 1987. Naturalised Birds of the World. Longman Scientific \& Technical, Harlow, Essex.

LONG, J. L. 1981. Introduced Birds of the World. The Worldwide History, Distribution and Influence of Birds Introduced to New Environments. David \& Charles, London.

MANLY, B. F. J. 1991. Randomization and Monte Carlo Methods in Biology. Chapman and Hall, London.

MARUYAMA, T. AND FUERST, P. A. 1985. Popuation bottle- necks and nonequilibrium models in population genetics. II. Number of alleles in a small population that was formed by a recent bottleneck. Genetics, 111, 675-689.

McCOMmAS, S. A. AND BRYANT, E. H. 1990. Loss of electrophoretic variation in serially bottlenecked populations. Heredity, 64, 315-321.

MERILÄ, J., BJÖRKLUND, M. AND BAKER, A. J. 1996. Genetic population structure and gradual northward decline of genetic variability in the Greenfinch (Carduelis chloris). Evolution (in press).

MOLINA-FREANER, F. AND JAIN, S. K. 1992. Isozyme variation in Californian and Turkish populations of the colonizing species Trifolium hirtum. J. Hered., 83, 423-430.

NEl, M. 1978. Estimation of average heterozygosity and genetic distance from a small number of individuals. Genetics, 89, 583-590.

NEI, M. 1986. Definition and estimation of fixation indices. Evolution, 40, 643-645.

NEI, M., MARUYAMA, T. AND CHAKRABORTY, R. 1975. The bottleneck effect and genetic variability in populations. Evolution, 29, 1-10.

NOVAK, S. J. AND MACK, R. N. 1993. Genetic variation in Bromus tectorum (Poaceae): comparison between native and introduced populations. Heredity, 71, 167-176.

PARKIN, D. T. AND COLE, S. R. 1985. Genetic differentiation and rates of evolution in some introduced populations of the House Sparrow, Passer domesticus in Australia and New Zealand. Heredity, 54, 15-23.

POLANS, N. O. AND ALLARD, R. w. 1989. An experimental evaluation of the recovery potential of ryegrass populations from genetic stress resulting from restriction of population size. Evolution, 43, 1320-1324.

PORTER, A. H. 1990. Testing nominal species boundaries using gene flow statistics: the taxonomy of two hybridizing admiral butterflies (Limenitis: Nymphalidae). Syst. Zool., 39, 131-147.

RAYMOND, M. AND ROUSSET, F. 1995a. GENEPOP (Version 1.2): population genetics software for exact tests and ecumenicism. J. Hered., 86, 248-249.

RAYMOND, M. AND ROUSSET, F. 1995b. An exact test for population differentiation. Evolution, 49, 1280-1283.

RICE, w. R. 1989. Analyzing tables of statistical tests. Evolution, 43, 223-225.

ROGERs, J. S. 1972. Measures of Genetic Similarity and Genetic Distance. University of Texas Publ. no. 7213, pp. 145-153.

Ross, H. A. 1983. Genetic differentiation of Starlng (Sturnus vulgaris: Aves) in New Zealand and Great Britain. J. Zool., Lond., 201, 351-362.

SAlTOU, N. AND NEl., M. 1987. The Neighbor-Joining method: A new method for reconstructing phylogenetic trees. Mol. Biol. Evol., 4, 406-425.

SLATKIN, M. 1993. Isolation by distance in equilibrium and non-equilibrium populations. Evolution, 47, 264-279.

SOKAL, R. R. AND ROHLF, F. J. 1981. Biometry, 2nd edn. Freeman, New York.

ST. LOUIS, V. AND BARLOW, J. C. 1988. Genetic differentiation among ancestral and introduced populations of the Eurasian tree sparrow (Passer montanus). Evolution, 42, 
$266-276$.

SCHWAEGERLE, K. E. AND SCHAAL, B. A. 1979. Genetic variability and founder effect in the pitcher plant Sarracenia purpurea L. Evolution, 33, 1210-1218.

SWOFFORD, D. L. AND SELANDER, R. B. 1989. BIOSYS-1. A computer program for the analysis of allelic variation in population genetics and biochemical systematics. Release 1.7.University of Illinois, Urbana, IL.

TAYLOR, C. E. AND GORMAN, G. C. 1975. Population genetics of a "colonising" lizard: natural selection for allozyme morphs in Anolis grahami. Heredity, 35, 241-247.

TAYLOR, A. C., SHERWIN, W. B. AND WAYNE, R. K. 1995. Genetic variation of microsatellite loci in a bottlenecked species: the northern hairy-nosed wombat Lasiorhinus krefftii. Mol. Ecol., 3, 277-290.

TEMPLETON, A. 1980. The theory of speciation via founder principle. Genetics, 94, 1011-1038.

Thomson, G. M. 1922. The Naturalisation of Animals and Plants in New Zealand. Cambridge University Press, London.

vÁsquesz PHILlips, M. 1992. Population Differentiation of the House Finch (Carpodacus mexicanus) in North America and the Hawaiian Islands. M.Sc. thesis, Univer- sity of Toronto and Royal Ontario Museum.

VERSPOOR, E. 1988. Reduced genetic variability in first generation hatchery populations of Atlantic salmon (Salmo salar). Can. J. Fish. Aquat. Sci., 45, 1686-1690.

WADE, M. J. AND McCAULEy, D. E. 1988. Extinction and recolonization: their effects on the genetic differentiation of local populations. Evolution, 42, 995-1005.

WARWICK, S. I., THOMPSON, B. K. AND BLACK, L. D. 1987. Genetic variation in Canadian and European populations of the colonizing weed species Apera spica-venti. New Phytol., 106, 301-317.

WAtterson, G. A. 1984. Allele frequency after a bottleneck. Theor. Pop. Biol., 26, 387-407.

WEIR, B. S. AND COCKERHAM, C. C. 1984 . Estimating $F$-statistics for the analysis of population structure. Evolution, 38, 1358-1370.

WHITLOCK, M. C. AND McCAUleY, D. E. 1990. Some population genetic consequences of colony formation and extinction: genetic correlations within founding groups. Evolution, 44, 1717-1724.

WOLF, P. G. AND SOLTis, P. S. 1992. Estimates of gene flow among populations, geographic races, and species in the Ipomopsis aggregata complex. Genetics, 130, 639-647. 